\title{
KIRJOITUS
}

TALVIKKI AHONEN

\section{Koronapandemian varjo on pitkä}

K ommentoin tässä puheenvuorossa Suvi-Maria Saarelaisen ja muun tutkituon keskusteluun mukaan muutaman huomion oman tutkimusryhmäni tutkimuksesta Suomen ortodoksisen kirkon piiristä korona-aikana.

Kaikkineen voidaan todeta, että elämän merkityksellisyyden teema on asian ytimessä silloin kun puhutaan niistä vaikutuksista, mitä koronapandemian aiheuttamalla erikoisella ja haastavalla ajanjaksolla on ihmisten elämään ja tulevaisuuteen. Saarelainen avasi esityksessään elämän merkityksellisyyden sisältöjä, joihin liittyi muun muassa ihmissuhteet, kuuluminen, terveys, tasapaino ja eteenpäin suuntautuminen. Niitä tarkasteltaessa havaitaan, että korona-ajalla ja sen luomilla poikkeusoloilla on suora vaikutus kaikkiin niihin. Vaikka merkityksellisyyden lähteet ovat yksilölliset, ihmisten perustarpeet ovat kuitenkin hyvin samankaltaiset.

Kiinnostava löydös Saarelaisen ja tutkimusryhmän aineistossa oli se, että henkilön uskonnollisuus korreloi positiivisesti elämän merkityksellisyyden kokemuksen kanssa. Tämä vahvistaa käsitystä siitä, että uskonnollisilla yhteisöillä on merkityksensä nykypäivänä myös sekularisoituvissa yhteiskunnissa. Voi olla, että koronapandemian kaltaiset yhteiskunnalliset ja globaalit kriisit korostavat tavalla tai toisella ihmisten hengellisiä tarpeita. Valitettavasti vaikutus yhteiskunnassa on myös sellainen, että diakonian tarve kasvaa - ei ainoastaan akuutissa kriisissä, vaan vaikutukset yksilöiden arkeen voivat olla hyvinkin pitkäkestoisia, jolloin diakonian asiakkaat saattavat päätyä riippuvaisiksi väliaikaisiksi tarkoitetuista tukimuodoista. 
Saarelainen nosti esityksessään esille nuorten tilanteen hankaloitumisen ja etsivän nuorisotyön merkityksen. Jatkokysymyksenä tästä voisi esittää sen, että mitä jalkautuva, etsivä nuoriso- ja diakoniatyö käytännössä korona-aikana on? Mitkä ovat ne toiminnan ja tavoittamisen keinot tilanteessa, jossa fyysisen kohtaamisen mahdollisuudet ovat rajatut? Mitkä ovat diakonian uudet ympäristöt? Nuorten verkkoympäristöt ovat erilaiset kuin aikuisten, ja nuorten tavoittaminen edellyttää myös nuorten käyttämien verkkoympäristöjen käyttämistä. Diakoniatyö on ollut uusien haasteiden edessä, kun avuntarvitsijoiden määrä kasvaa ja globaali terveyskriisi on edelleen ajankohtainen. Meille tutkijoille diakoniatyön muutos kriisissä on äärimmäisen keskeinen kysymys.

Huoli nuorista on paitsi diakoniatyön myös laajemmin koko yhteiskunnan huoli. Kansainvälisen työjärjestö ILO:n elokuussa 2020 julkaiseman raportin mukaan nuorista erityisen epäedullisessa asemassa olevat ovat nuoret, 18-24-vuotiaat naiset köyhimmistä maista. Riskinä on, että kriisin aikaan työmarkkinoille tulevat nuoret joutuvat tyytymään mihin tahansa työhön mitä saavat, ja kriisi voi heijastua pitkälle näiden nuorten tulevaisuuteen muita heikompana ura- ja palkkakehityksenä (ILO, 2020). Myös työttömäksi jäävän työttömyys saattaa pitkittyä. Pitkäaikaistyöttömien lukumäärän kasvaessa herää huoli myös lasten tulevaisuudesta ja ylisukupolvisen työttömyyden ja huono-osaisuuden riskeistä. Köyhyyden ylisukupolvistuminen mainitaan myös vuoden 2020 diakoniabarometrissä yhtenä diakonian ajankohtaisista haasteista. (Alava ym., 2020.)

Lopuksi pohdin lyhyesti aihetta suhteessa oman tutkimusryhmämme tuloksiin. Tutkimme viime keväänä yhdessä Pekka Metson, Ari Koposen ja Mikko Punkin kanssa ortodoksisen kirkon jumalanpalveluselämään osallistuneiden kokemuksia striimatuista jumalanpalveluksista ja osallistumisesta sakramentteihin. Keräsimme kyselylomakkeella vastauksia, joita saimme yli 300 . Vaikka kyselymme ei kohdistunut suoraan merkityksellisyyden kokemuksiin, myös meidän aineistossamme oli paljon näihin aiheisiin liittyvää materiaalia. Suurin osa kysymyksistämme oli avoimia, ja ihmiset usein kertoivatkin laajasti omista elämäntodellisuuksistaan.

Tutkimuksemme vastaajajoukko koostui enimmäkseen kirkollisesti aktiivisista ortodokseista. Näiden vastaajien keskuudessa aineistosta nousi esiin etenkin koettu kaipaus kirkon perinteisiin, kirkkotilassa tapahtuvaan jumalanpalveluselämään. Moni vastaaja kertoi siitä, kuinka oli havahtunut jumalanpalveluselämän tärkeyteen arjessaan, ja huomasi kenties aiemmin pitäneen- 
sä mahdollisuutta jumalanpalveluksiin itsestäänselvyytenä elämässään. Kriisi toikin esille niitä arvoja ja merkityksiä, jotka on koettu tärkeiksi ja keskeisiksi, mutta jotka ovat olleet osittain piilossa olevia. Tämä on kenties osittain sama ilmiö kuin arvojen lujittuminen, jota Saarelainen esityksessään korosti.

Kysyttäessä vastaajien henkilökohtaisesta rukouselämästä monet kertoivat sen vaikeudesta ilman konkreettista yhteyttä seurakuntaan. Toisaalta ihmisillä oli selvästi hyvin erilaiset mahdollisuudet ja kyvyt luoda merkityssisältöjä striimatun jumalanpalveluselämän kautta. Osa koki suhteensa kirkkoon katkenneen täysin, kun taas osa koki suurempaa osallisuutta kirkosta kuin ennen koronakriisiä ja poikkeusoloja. Pandemian vaikutukset ovat siis tässäkin suhteessa hyvin paljon yksilöstä ja hänen kokonaiselämäntilanteestaan riippuvaisia.

Diakoniaan liittyen haluan vielä nostaa esille yhden yksittäisen huomion aineistostamme: muutamat vastaajat harmittelivat sitä, että eivät voi vapaaehtoisina osallistua diakoniatyöhön, jonka he kokivat tärkeäksi asiaksi elämässään. Diakoniatyö ei ole siis merkityksellistä ainoastaan sen kohderyhmille, vaan myös sen tekijöille. Seurakuntayhteisöissä on tarvetta ja halua voida palvella muita, ja seurakuntalaisten keskinäinen kohtaaminen ja tuki etsii uusia väyliään ja muotojaan.

Kommenttipubeenvuoro Suvi-Maria Saarelaisen esitykseen Merkityksellisyyden kokemus korona-aikana Diakonian ja kasvatuksen tutkimuspäivässä 26.11.2020.

\section{Kirjallisuus}

Ahonen, T., Koponen, A., Punkki, M. \& Metso, P. (2020). Lähentymistä ja etääntymistä korona-aikaan].https://ort.fi/ uutishuone/2020-11-24/lahentymista-ja-etaantymista-korona- aikaan - viitattu 15.11.2021.

Alava, H., Kela, A., Nikkanen, A. \& Paloviita, P. (2020). Diakoniabarometri 2020. Aina uuden edessä.Suomen ev.-lut. kirkon julkaisuja 88. Helsinki: Kirkkohallitus. https://evl.fi/ documents/1327140/0/31446640_Diakoniabarometri-tutkimusraportti_verkkojulkaisu_20_08_24.pdf/0d769ae2-fbc5-a18ef7f9-b0f54c8d7ae1?t=1600684512167

- viitattu 15.11.2021.
International Labour Organization (2020). Youth and Covid-19. Impacts on Jobs, Education, Rights, and Mental Well-being. https://www.ilo.org/wcmsp5/groups/public/---ed_emp/documents/publication/ wcms_753026.pdf - viitattu 15.11.2021.

Punkki, M., Koponen, A., Metso, P. \& Ahonen, T. (2021). Yhteydessä erilliset: Selvitys koronaepidemian vaikutuksista Helsingin ortodoksisen hiippakunnan jäsenten kokemuksiin jumalanpalveluselämästä. Helsinki: Helsingin ortodoksinen metropoliittakunta. 